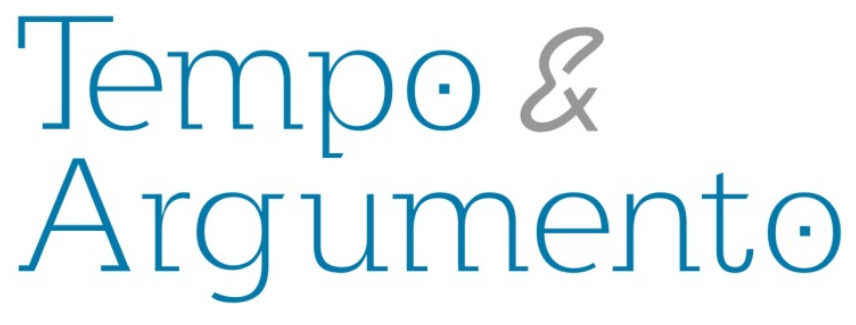

\title{
Historias cotidianas y Los rubios: dos formas de narrar el pasado
}

\begin{abstract}
Resumen
Según Gustavo Aprea (2015) hay tres modalidades de abordaje que plantean los documentales sobre la militancia que participó de los hechos ocurridos durante la Dictadura Militar Argentina (1976-1983): la primera; desde la vivencia y lo testimonial, la segunda desde la memoria y el no-olvido, y la tercera desde la posibilidad de transmisión de la experiencia de la militancia revolucionaria que construye modelos para las nuevas generaciones. Los primeros relatan la historia desde la derrota y con una lectura política, los segundos desde el trauma y con una lectura personal, y los terceros desde el reconocimiento y con una lectura profesional de los hechos. En este artículo se desarrollará el segundo grupo desde el análisis de las películas Historias cotidianas (2001) de Andrés Habegger y Los rubios (2003) de Albertina Carri, quienes reconstruyen la militancia desde lo afectivo, buscando un cierre a una etapa de sus vidas por medio de una memoria fragmentada. Si bien ambos documentales son guionizados y dirigidos por hijos de desaparecidos en la época de Terrorismo de Estado, ya desde el título se encuentra una diferencia marcada en su abordaje temático, que se visualiza también en el tratamiento estéticonarrativo. Por ende, el presente artículo tiene como objetivo llevar adelante un análisis narrativo (contemplando estructura y recursos) de ambas obras y, a su vez, tratar de comprender sus mensajes, sus significados, a la luz de la teoría expuesta por múltiples estudiosos del cine documental político, con el fin último de poder establecer un punto de encuentro.
\end{abstract}

Palabras clave: Documental Político. Memoria. Narración Audiovisual.

\section{Para citar este artículo:}

MORAZZO, María Virginia. Historias cotidianas y Los rubios: dos formas de narrar el pasado.

Tempo e Argumento, Florianópolis, v. 9, n. 21, p. 132 - 152, maio/ago. 2017.

\author{
María Virginia Morazzo \\ Doctorado en Artes de la Universidad Nacional \\ de las Artes (UNA). \\ Buenos Aires - ARGENTINA \\ virginiamorazzo@gmail.com
}

DOI: $10.5965 / 2175180309212017132$

http://dx.doi.org/10.5965/2175180309212017132 


\section{Historias cotidianas and Los rubios: two forms to narrate the past}

\begin{abstract}
According to Gustavo Aprea (2015) are three modalities that the documentaries about militancy show the facts occurred during the Military Dictatorship Argentina (1976-1983): the first, from the testimony, the second from the memory and the no-forget and the third from the possibility of transmission of the experience that build models. The first one relate the history from the defeat and with a political reading, the seconds from the trauma and with a personal reading, the third from the recognition and with a professional reading of the facts. In this article will develop the second group from the analysis of the films Historias cotidianas (2001) of Andrés Habegger and Los rubios (2003) of Albertina Carri, those who reconstruct the militancy from the affective, looking for a closing to a stage of his lives by means of a fragmentary memory. Although both documentaries are wrote and directed by ex-missing childrens in the period of Terrorism of State, already from the title finds a marked difference in his thematic boarding, that visualizes also in the aesthetic treatment-narrative. Therefore, the objective of the present article is to carry on a narrative analysis (contemplating structure and resources) of both films and, to his time, work with his messages, his meanings, To the light of the exposed theory by multiple studies of political cinema, with the end task to be able to establish a meeting point.
\end{abstract}

Keywords: Political Documentary. Memory. Audiovisual Narrative.

\section{Historias cotidianas e Los rubios: duas formas de narrar o passado}

\section{Resumo}

Segundo Gustavo Aprea (2015) há três modalidades de abordagem que propõem os documentários sobre a militância que participou dos fatos ocorridos durante a Ditadura Militar Argentina (1976-1983): a primeira, desde a vivência e o testemunhal, a segunda desde a memória e o não-esquecimento e a terceira desde a possibilidade de transmissão da experiência de militância revolucionária que constroem modelos para as novas geraçõe. Os primeiros relatam a história desde a derrota e com uma visão política, os segundos desde o trauma e com uma visão pessoal, e os terceiros desde o reconhecimento e com uma visão profissional dos fatos. Neste artigo será desenvolvido o segundo grupo desde a análise dos filmes Historias cotidianas (2001) de Andrés Habegger e Los rubios (2003) de Albertina Carri, nos quais os autores reconstroem a militância desde o afetivo, procurando fechar uma etapa de suas vidas por médio de uma memória fragmentada. Embora os dois documentários têm roteiros e são dirigidos por filhos de desaparecidos na época de Terrorismo de Estado, já desde o título encontra se uma diferença marcada na sua abordagem temática, que pode ser visualizada também no tratamento estético-narrativo. Portanto, o presente artigo tem como objetivo levar adiante uma análise narrativa (contemplando estrutura e recursos) de ambas as obras e, ao mesmo tempo, tentar compreender as suas mensagens, seus significados, à luz da teoria exposta por múltiplos estudiosos do cinema documentário político, com a finalidade última de conseguir estabelecer um ponto de encontro.

Palavras-chave: Documentário Político. Memória. Narração Audiovisual. 
Historias cotidianas y Los rubios: dos formas de narrar el pasado.

El pasado ya no es un horizonte transparente y compartido por la obra y el espectador, sino el sitio en que opera un complejo de memorias que será necesario activar, procesando e interrogando los recuerdos personales de los testimoniantes, los archivos fotográficos, sonoros y audiovisuales, y las huellas de lo pretérito en el tejido social contemporáneo. (PIEDRAS, 2014, p. 183)

Historias cotidianas (2001) y Los rubios (2003) son dos documentales argentinos guionizados y dirigidos por hijos de desaparecidos en la época del Proceso de Reorganización Nacional (1976-1983) en la Argentina: Andrés Habegger y Albertina Carri, respectivamente. Podemos afirmar que se trata de obras artísticas que hacen referencia a un período histórico muy significativo, aún en estos días, en nuestro país y ya desde el título ${ }^{1}$ encontramos una diferencia marcada en su abordaje temático, que se visualiza también en el tratamiento estético-narrativo. Esto pareciera separarlas en los extremos más disímiles de lo denotativo versus lo connotativo, pero en realidad a estos directores los une el sentimiento sobre estos hechos traumáticos que marcan su presente y la búsqueda de alivio, por medio de su obra. Por eso, sus films son historias que no cierran, son estructuras narrativas abiertas, fragmentadas, parciales, que ponen en evidencia el trabajo con la memoria individual y lo emocional, que pretenden resaltar el no-olvido, la búsqueda inacabada de la identidad y escapan de la idea de analizar las causas de los hechos. Gustavo Aprea sostiene que éstos son obras audiovisuales que manifiestan los conflictos y las rispideces entre la memoria individual y la memoria colectiva, poniendo en discusión las distintas interpretaciones sobre los hechos ocurridos.

Por tanto, el presente artículo tiene como objetivo llevar adelante un análisis narrativo (contemplando estructura y recursos) de ambas películas y, a su vez, tratar de comprender sus mensajes, sus significados, a la luz de la teoría expuesta por múltiples estudiosos del cine documental político, con el fin último de poder establecer un punto de encuentro.

\footnotetext{
${ }^{1}$ En el caso de la película de Andrés Habegger, su título explicita claramente, denotativamente, a qué refiere: "historias cotidianas", historias comunes de personas comunes, que vivieron el mismo hecho histórico. En cuanto al documental de Albertina Carri, su título es una figura retórica, una metonimia que alude a su familia, tiene un significado connotativo: en los años setenta, época en que desaparecen los padres de la directora, los Carri eran identificados por sus vecinos como "los rubios".
} 


\section{El documental}

Diferenciar el documental y la ficción ha sido tarea difícil y siempre controvertida. María Luisa Ortega manifiesta que estamos transitando un cambio en la concepción sobre hacer cine. Se puede decir que hay una hibridación entre lo real y lo ficticio, entre lo objetivo y lo subjetivo. Por lo cual, debería pensarse en redefinirse lo que llamamos documental.

El cine documental ha manifestado y manifiesta una voluntad de compromiso cognitivo con el espectador, de generar conocimiento sobre la realidad social en primera instancia, aunque en un proceso de constante negociación en las formas y estableciendo otros vínculos comunicativos de naturaleza estética y emocional ligados irremisiblemente a él... (ORTEGA, 2005, p. 188)

Con esto queda claramente expresada la tensión entre la experimentación del lenguaje, la utilización de recursos diversos, para brindar cierto conocimiento de lo social (como considera Ortega, el documental se ha creado como un cine de lo social) y el contrato de credibilidad establecido con el espectador sobre qué está viendo. Por eso es que una de las diferencias marcada con mayor frecuencia entre formatos ha sido el vínculo que entabla la obra con su espectador: Chanan (2011, p. 46) determina que el documental "le habla al espectador como ciudadano" en contraposición a la ficción que interpela al receptor desde lo emotivo o, como lo menciona Nichols, el documental se vincula con el placer de conocimiento, el compromiso social, y la ficción se relaciona con el placer de mirar.

Tal como dice Corner el documental no puede ser considerado como tal por su estética, forma, objetivos o temas, ya que esa demarcación para su estudio resulta escasa y siempre problemática. Esta es la razón por la cual este teórico, al igual que otros, focaliza la conceptualización en el perfil cognitivo del documental y con ello en el análisis del origen y organización de las imágenes, es decir, la intervención del director en la película (registro y edición de imágenes).

El documental argentino hasta los años noventa, en general, ha reproducido la historia por medio de una narración basada en lo "causal, unilineal, coherente, transparente" (PIEDRAS, 2014, p. 152), pero a partir de allí hubo un predominio de lo 
performativo, lo reflexivo, el testimonio y la experiencia, lo cual de alguna manera rompe con aquella forma de relato sin perder por ello la coherencia. Así, es como el realizador se interpone por medio de su experiencia personal en la experiencia colectiva, histórica, o dicho de otra forma, el sujeto se ubica en el vínculo entre la memoria colectiva y la memoria personal (Maurice Halbwachs).

Asimismo, en el nuevo siglo se mantiene el cambio de paradigma en la forma de vincular el relato audiovisual con la historia: basado en la performatividad, lo expresivo porque "el mundo histórico es un horizonte sobre el cual se recortan e inscriben relatos personales" (PIEDRAS, 2014, p. 167). Por esta razón, el acento puesto en los elementos estético-narrativos del film es una manera de manifestar la posición personal del director en contraposición a su dilución en el documental más clásico. Para explicar mejor este punto, se tomarán como base las estrategias audiovisuales tanto clásicas como heterodoxas propuestas por María Luisa Ortega, las cuales marcan esa visión particular de autoría que busca colarse en el documental actual. Por un lado, está lo que ella llama "la domesticación de la fragmentación", es decir, la relevancia de las metáforas, yuxtaposiciones y resonancias visuales, poética sonora, la estructura no clásica que ayuda a plasmar una idea abstracta y se vuelve una vía de argumentación, sin caer en lo concreto de los acontecimientos. Por otro lado, están "las temporalidades y narrativas" que apuestan a una estructura no-dramática de representación apuntando a otras temporalidades que no sean necesariamente causales, sino más bien personales, subjetivas, dirigidas por la memoria, fragmentadas y en espiral. Esto lleva justamente hacia otro recurso, "las subjetividades", la voz narrativa en primera persona, un yo que busca auspiciar de mediador de una experiencia que es investigada y abordada desde lo personal, no desde el conocimiento superior a otros. $\mathrm{Y}$ por último, se puede hacer referencia a las "reconstrucciones", a las dramatizaciones de lo real como recurso narrativo; sin embargo en el nuevo documental apunta a esta técnica como forma de “jugar” con el lenguaje clásico.

En coincidencia con John Corner, se puede afirmar que tanto éstas como otras intenciones por definir o clasificar el documental serán insuficientes dado que "cómo los documentales intentan permitirnos el acceso al mundo y ofrecernos propuestas explícitas 
e implícitas y juicios sobre ello es todavía un asunto rico y poco desarrollado." (CORNER, 2012: 18)

\section{El documental político}

Si bien es complejo definir o delimitar el cine documental, más complejo resulta caracterizar, conceptualizar el cine documental político. Se puede comenzar diciendo que todo depende del momento en que se produzca y reciba dicho cine y, además, puede ser político de diversas maneras, ya sea por su contenido, ya sea por el punto de vista del realizador sobre un hecho (forma en que lo aborda), ya sea la mirada del espectador sobre el audiovisual. Pablo Piedras en su texto Cine político y social: un acercamiento a sus categorías a través de sus debates y teorías (2009) menciona a varios estudiosos que analizan el documental político. García Escudero vincula lo político al tema, sin considerar lo formal; en cambio, el crítico Ciriaco Tiso propone dos maneras de considerar al cine político, sea por su tema, sea por su forma. Zimmer estaca el vínculo obra/espectador/contexto, resaltando que "el cine político es un cine del presente, incluso cuando hable del pasado.". Chanan (2011, p. 58) sostiene que el documental político tiene múltiples temas, voces y audiencias "pero el momento político nace en el acto mismo de observar". Por su parte, Hennebelle propone una definición muy similar a la considerada por Birri en su manifiesto, donde destaca que el cine documental político debe ser nacional, moderno, realista, popular y un arte de incitación.

Con respecto al cine político argentino de los últimos veinticinco años

Resurgió en nuestro país a la par de la agudización de los conflictos sociales en general y de la revalorización del género documental en particular. Es en estos años cuando crece el interés por el cine documental, y en paralelo con el documental de autor, comienzan a formarse colectivos de cine social y político. (DE LA PUENTE Y RUSSO, 2011, p. 131).

Ahora, si se tiene en cuenta que la época de la Dictadura Militar en la Argentina ha sido uno de los conflictos sociales más aberrantes que ha marcado su historia y se quiere focalizar en la forma en que fueron abordados desde el documental en múltiples 
ocasiones, se puede considerar la clasificación que propone Aprea. Este teórico plantea tres modalidades de abordaje de los documentales sobre la militancia de estos sucesos: la primera, desde la vivencia y lo testimonial, la segunda desde la memoria y el no-olvido ("memoria airada"²) y la tercera desde la posibilidad de transmisión de la experiencia que construyen modelos. Los primeros relatan la historia desde la derrota y con una lectura política, los segundos desde el trauma y con una lectura personal, los terceros desde el reconocimiento y con una lectura profesional de los hechos.

Dado el corpus de películas planteadas al inicio se va a analizar el segundo grupo propuesto por este autor, ya que los documentales Historias cotidianas de Andrés Habegger y Los rubios de Albertina Carri reconstruyen la militancia desde lo afectivo, buscando un cierre a una etapa de sus vidas por medio de una memoria fragmentada. En el caso de Carri, por un lado, su protagonismo es directo con lo que narra porque busca su pasado, pero indirecto en muchos casos porque una actriz la interpreta ${ }^{3}$. Sin embargo, Habegger es claramente un protagonista indirecto de los acontecimientos relatados ya que si bien comparte con los protagonistas del documental el hecho de "ser hijos de", refiere su obra a las historias de otros seis personajes y no a la propia.

\section{Los documentales políticos Historias cotidianas y Los rubios: análisis desde la} narrativa

Desde la narratología ${ }^{4}$ la forma de narrar refleja el cómo se cuenta una historia desde una perspectiva dada, por medio de una hipótesis determinada.

\footnotetext{
${ }^{2}$ Concepto analizado por Paula Rodríguez Marino (2013): “...una estrategia de representación de la memoria traumática y una forma de representación cultural. (...) se identifica con la querella y mantiene el pasado en el presente (...) La "memoria airada" surge en la medida en que se percibe o hay una prohibición sobre la memoria." (139-161)

${ }^{3}$ Cuando se mencione a "Albertina" (entre comillas), estaremos haciendo referencia a Analía Couceyro, es decir, la actriz que interpreta a Albertina Carri en el documental Los rubios.

${ }^{4}$ Su estudio ha tenido antecedentes desde Aristóteles, pasando por los Formalistas Rusos y teniendo su momento más relevante durante el Estructuralismo. Algunos de los teóricos más importantes han sido Genette, Greimas, Barthes, entre otros.
} 
Toda narración refiere una serie de acontecimientos ligados entre sí. Implica la narración del tiempo, pero para una narración no basta con una simple sucesión. (...) Pero también es cierto que estamos acostumbrados a ordenar la experiencia en acontecimientos que no siempre responden a una secuencia. Agrupamos la experiencia en torno a núcleos centrales, a parcelaciones de la realidad, por metonimias, por contigüidades no siempre secuenciales... (VILLANUEVA, 1994, p. 223)

Si bien el tema general en los documentales mencionados es el mismo (historias de hijos de desaparecidos), la hipótesis de trabajo es diferente y la forma de construir el relato varía en ambos films, comenzando por la modalidad documental elegida por sus directores. En el caso de Los rubios se puede decir que se trata de un documental performativo según las modalidades expuestas por Bill Nichols, en el cual la subjetividad del realizador toma protagonismo y legitima el contenido de lo expuesto como real: es un relato en primera persona que trata sobre los recuerdos de Albertina Carri con respecto a sus padres Roberto Carri y Ana María Caruso, quienes fueran secuestrados y desaparecidos durante el mismo momento histórico. Esta modalidad pone en tela de juicio el formato de documental más clásico y propone una frontera difusa con la ficción, busca la poesía visual y sonora, privilegia el plano connotativo, evocativo, más que el denotativo, referencial. Por ejemplo, Carri muestra en pantalla las idas y vueltas de lo que sucede detrás de cámara con la realización de su película con la intención clara de desdibujar los límites entre realidad y ficción. Todos los recursos fueron puestos a trabajar para que la directora de Los rubios intente reconstruir parte de su pasado apelando a su memoria y terminando por aceptar que nunca podrá reconstruir completamente aquello que pasó. En cambio, Historias cotidianas se trata de un documental interactivo, modalidad que expone la relación entre el realizador y el sujeto filmado, que pone el énfasis en los testimonios y en las imágenes de demostración que apoyan dichos discursos, transformándose así en la argumentación de los hechos. Esta modalidad incorpora la impresión de "presencia situada" y de conocimiento preciso que nace del vínculo director/testimoniante. Así, en Historias cotidianas el relato coral se estructura en torno al testimonio de seis hijos de desaparecidos (Cristian Czainick, Florencia Gemetro, Victoria Ginzberg, Martín Mortola Oesterheld, Úrsula Méndez y Claudio Novoa) y sus historias son hilvanadas en bloques o capítulos atravesados por lineamientos temáticos: 
huellas, hijos, historia, hoy. La narración se apoya no sólo en los recuerdos de sus protagonistas, sino en sus sentimientos hoy con aquello que les pasó, centrado en la palabra y lo emocional, despojado de artilugios "sensacionalistas".

Otras diferencias entre estas películas, a veces más marcadas y a veces menos visibles, están dadas por el uso de recursos típicos del documental que modelan sus estructuras. Tal como lo menciona Campo en Documental político argentino (2007-2012) hay procedimientos que colaboran en la construcción de un relato, tales como la voz over, las imágenes de archivo, el directo y los testimonios/entrevistas.

Se puede decir que en el documental de Habegger predomina este último recurso por sobre los otros y los restantes complementan al testimonio.

La presencia es inseparable del valor de verdad que adquiere el testimonio amarrado al testimoniante, por ello los testimonios en los documentales están en in, más allá de que se intercalen imágenes que dejen momentáneamente en off al relato. Pero testimonio no significa «entrevista»: «lo que se pone por delante en todos estos casos, más que la exposición de información (entrevista), es la transmisión de una experiencia» (Aprea, 2012: 126). El testimonio en el cine puede hacer lo que la literatura no, según tomás Crowder-Taraborrelli y Kristi Wilson, la conjunción de imagen y sonido «tiene la extraordinaria habilidad para representar el proceso del trauma [...] Entonces, el film opera como un vehículo de duelo y memoria» (2012: Viii-Xi-15). (CAMPO, 2016, p. 12)

En Los rubios, el uso del recurso del testimonio está alejado de la idea clásica de busto parlante tal como la utiliza Habegger. Por un lado, tenemos el relato de los familiares y amigos de la directora que hablan sobre sus padres pero lo vemos por medio de un videocasete grabado en un televisor, no en directo. Por otro lado, vemos a “Albertina" contando los vagos recuerdos sobre su infancia. En definitiva, el discurso siempre está mediado, en realidad, hipermediado tecnológica o personalmente: se ve en la pantalla un relato que está atravesado por otra pantalla o se ve un relato de alguien representado por otro (Analía Couceyro habla a cámara como si fuese Albertina Carri).

Como se puede observar en Historias cotidianas no hay voz en over, no hay narrador, sólo oímos las voces de los protagonistas, ya sea hablando a cámara, ya sea en off sobre las imágenes de su propia narración o sobre las imágenes de los otros, como un 
modo de establecer los cruces de sus historias personales y, a la vez, unidas por el dolor de un mismo hecho. Esto le otorga al relato una personalización, se adentra así en lo individual, en lo emotivo y descarta la posibilidad de un audiovisual guiado por una entidad omnisciente, suprema, solemne, que todo lo sabe. De forma similar se utiliza en Los rubios y con esto nos referimos a la ausencia de ella, o sea, la directora prefiere hacer uso de la voz en off de ella misma, de la actriz que la interpreta o de alguien de su equipo. Manifiesta Javier Campo (2016, p. 6) que "La voz over en el cine documental tiene la particularidad de hacernos «creer que estamos oyendo a la historia o a la realidad hablándonos a través del film, pero lo que escuchamos es la voz del texto, incluso cuando esa voz trata de difuminarse a sí misma», afirma Bill Nichols (1997, p.52)." Con lo cual, estaría muy lejos de lo que Carri quiere plasmar en su película: una visión subjetiva de sus recuerdos, una búsqueda personal de su pasado, más que de la historia.

Por otra parte, tal como sucede en la mayor parte del cine documental político argentino no hay preeminencia del registro directo, en la película de Habegger únicamente pueden apreciarse pequeñas intervenciones de manifestaciones de los años setenta y más actuales (como el video de las marchas de HIJOS5) que "sólo sirven como una ilustración, una viñeta que permite despejar o reflexionar al espectador entre densos bloques de parlamentos" (CAMPO, 2016, p. 12). En Los rubios el trabajo es muy diferente, se focaliza, desde la actualidad, en el registro símil noticiario de imágenes en una charla informal con los vecinos del barrio de su niñez. Con ello la directora apela a los recuerdos que estos puedan tener sobre ese momento que ella intenta reconstruir, lo cual de alguna manera marca una vez más lo difuso, lo fragmentado del discurso. En este caso, se hace referencia a un recurso heredero del cinema-verité con el cual, tal como lo menciona Ortega (2005, p. 196), "la puesta a punto de la cámara como dispositivo provocador y catalizador al servicio de la encuesta social..." nos llevan a presenciar un registro no esquematizado, no guionizado, de índole más natural. Y otra vez Carri se vincula con él de forma colateral: una vecina habla a través de una reja, los niños hablan con "Albertina”, la vecina habla con el productor del equipo (el cual ella integra “de costado”).

\footnotetext{
${ }^{5}$ Acrónimo de Hijos e Hijas por la Identidad y la Justicia contra el Olvido y el Silencio. Es una organización de derechos humanos de la Argentina fundada en 1994.
} 
Por último, el material de archivo en el largometraje de Habegger es relativamente escaso (no satura la pantalla) y se conecta más con lo sentimental que con lo meramente ilustrativo de las ideas expuestas por los testimoniantes. Con esto se quiere indicar que la mayor parte de la presencia de material de archivo son fotos personales de la niñez de los protagonistas, cartas escritas a sus padres siendo pequeños o el video de la lucha de HIJOS. La excepción a esto son algunas intervenciones de imagen/sonido de archivo que sirven para ubicar temporalmente la época del Proceso Militar: tapas de diarios de los años setenta, imágenes fijas o móviles de la misma época y audios de sonido ambiente, un fragmento del discurso de Videla y del juicio al mismo. Este recurso es muy escaso también en la película de Carri, pero difiere ya que la directora no utiliza imágenes de archivo en ningún momento sobre el momento histórico al que hace referencia. Lo que tiene que ver con archivo en Los rubios solamente está vinculado a fotografías personales de la directora y su familia, cartas personales, libros y algún artículo escrito por su padre, los cuales son expuestos, generalmente, de forma indirecta: colgadas en una pared, puestas sobre un escritorio o como parte de un rejunte de elementos sobre los que "Albertina" observa su pasado, es decir, se produce una manipulación del material de archivo siempre de la mano de Analía Couceyro y no llega a verse en detalle. En ambos documentales, la poca utilización de este recurso se condice con la focalización en la huella emocional que dejó un suceso histórico (y no resaltar el suceso en sí mismo que es lo que se busca destacar, generalmente, con las imágenes de archivo).

Otro procedimiento, hasta aquí no analizado y más propio del docudrama, es la dramatización o ficcionalización de escenas de las cuales no se cuenta con un registro y con lo cual intenta darse un impacto emocional mayor a determinado suceso. Podemos decir que esta estrategia es utilizada por Carri pero justamente con un efecto inverso, el del distanciamiento de lo dramático. ¿Cómo logra esto Albertina Carri? Dejando el relato expuesto en su artificialidad, tanto cuando se presenta ante cámara Albertina indicándole a "Albertina" qué debe decir o la repetición en varias ocasiones del mismo texto evidenciando la grabación de múltiples tomas de lo mismo. También con la ficcionalización del momento del secuestro de sus padres, entre otros, recreado con Playmobil, en vez de personas ya que, como dijo Albertina en una entrevista con Mariano Kairuz (2008) "la animación es una gran amiga que acá me ayudó a representar lo 
irrepresentable". Todo esto le quita el impacto trágico a los hechos pero plasma otro nivel narrativo: la perspectiva de la niña que era cuando secuestraron a sus padres. Paradójicamente, si bien se habla de una película personal, subjetiva, lo cual por lógica debería causar un efecto emocional en el espectador, la utilización de estos recursos hasta aquí plasmados demuestran lo contrario. Así lo expresa Carri en una entrevista para el Grupo Kane:

Para mí, evidenciar al cine en sí mismo era algo necesario para el relato. No sólo porque quería contar el derrotero de mi equipo intentando contar una película sobre lo sucedido (hay una frase que lo deja claro: "tengo que encontrar algo, algo que sea película") sino que sentía que era necesario exponer ciertos mecanismos para generar distancia en el espectador... Me parecía totalmente innecesaria la catarsis ya que creía que lo importante era alejar al espectador del drama y que pueda verlo sucedido de otra manera... en Los rubios intenté evitar profundamente la catarsis. Quería correrme de la posibilidad de que un espectador vaya al cine, se siente, llore un rato y diga "bueno, ya está, conocí a Roberto y Ana María". Yo quería todo lo contrario, que el espectador entienda la verdadera imposibilidad de conocerlos. (CIRULO, 2013)

Pero las distinciones no culminan en este punto, las estructuras narrativas de estos documentales también difieren organizativamente.

La disposición de los acontecimientos en Historias cotidianas posee una anisocronía ineludible, es decir, una alteración en el ritmo narrativo entre la realidad y lo que se cuenta. Esta falta de correspondencia se traduce en tres procedimientos narrativos: orden, duración y frecuencia.

En el primer caso, hay evocaciones (analepsis ${ }^{6}$ ) ya que los entrevistados hablan de su pasado, del recuerdo que tienen de sus padres o de aquello que le contaron sobre ellos, pero también de cómo esto los afecta hoy ${ }^{7}$ e, incluso, en algunos casos, cómo

\footnotetext{
${ }^{6}$ En Narratología, se denomina Analepsis a toda evocación posterior de un acontecimiento anterior al punto de la historia.

7 Explica Andrés Habegger en una nota: "Yo partía -agrega- de una premisa personal básica: cuando desapareció mi viejo, lo primero que sufrí fue su ausencia como padre. Después pude saber y enterarme de cuál fue la causa de su desaparición. Pero como niño, lo primero que sufrí fue que él no estuviera. Y nos interesaba trabajar sobre ese aspecto. Porque hubo una generación que vivió de costado aquella violencia cotidiana. Al decir de costado, me refiero a que éramos niños. Es distinto hablar de la generación que militaba, que tenía un compromiso surgido de una elección propia. Quisimos ver qué pasa hoy con los que entonces éramos chicos, cuáles son las marcas o huellas en esta generación que tiene entre 20 y 30 años". (http://www.lanacion.com.ar/56936-jovenes-en-un-film-por-la-memoria)
} 

perpetradores de los crímenes de lesa humanidad con la finalidad de conseguir la condena social, "que este país sea su cárcel”, ya que no creía en ese momento que se lograra la justicia legal. Victoria Ginzberg es periodista (y paradójicamente, la que menos habla), se vincula con actividades que tienen relación con los derechos humanos y en esta película busca todo el tiempo el lugar donde se sacó una de las últimas fotos con sus padres y quizá sea ello una metáfora de su búsqueda interna. Martín Mortola Oesterheld perdió a varios integrantes de su familia, entre ellos a su abuelo, el creador de la historieta El Eternauta, y considera que el hecho de haber tenido un hijo tan joven fue como una necesidad de rearmar su historia, de tener algo propio, "de tener una familia". Úrsula Méndez logró despedirse de su madre ya siendo grande con un homenaje en el departamento del cual se la llevaron para “dejar la marca de la pérdida”. Claudio Novoa (de nacimiento Manuel Goncalvez) fue dado en adopción y descubrió hace unos años que sus padres habían muerto lo cual le permitió cerrar la historia de alguna forma y, además, se enteró que tenía un hermano (músico del grupo Los Pericos), con el cual se cruzó varias veces sin saberlo, y satisfecho con eso sostiene que "sería bueno que cada uno encuentre su propia historia" (con esta expresión de deseo se cierra la película). Con respecto a Los rubios y el orden de los sucesos, hay un presente en el discurso que muestra la construcción de parte del relato que puede verse en pantalla (el equipo de filmación), hay un presente ficticio del contenido de la película construido por “Albertina”, hay evocaciones (analepsis) por medio del discurso directo de los vecinos y los testimonios de amigos y familiares, pero también hay una proyección (prolepsis ${ }^{8}$ ) al final del relato donde la directora muestra indirectamente ("los rubios" se alejan en el campo) cómo se proyecta a partir de esta experiencia, donde muestra que esta etapa le permite continuar con "el pasado a cuestas" porque tiene una "familia" que la acompaña.

\footnotetext{
${ }^{8}$ En Narratología, se denomina Prolepsis a toda maniobra narrativa que consista en contar o evocar por adelantado un acontecimiento posterior.
} 
En el segundo caso, para adecuar el tiempo de la historia real al tiempo del relato audiovisual pueden utilizarse variados recursos, en este documental el director prefirió destacar momentos precisos y por ello debió valerse irremediablemente de las elipsis temporales y del resumen (o condensación de la información de hechos que se extendieron en los años en sólo unos minutos). Por otra parte, dado que es un film focalizado en la individualidad, se hizo utilización del recurso de la pausa descriptiva, el cual de alguna manera detiene el relato en el tiempo y, en este caso, lo focaliza en un momento emotivo. Por ejemplo, cuando Úrsula describe el sueño recurrente que tiene con su madre: "era una espera con muchas ganas, una espera donde después a lo largo de los años se tradujo en un sueño reiterativo que tengo constantemente... que es que cuando nos encontramos, sueño que nos encontramos, y es tal como la emoción de ver que ella está viva y que vuelve, que hay una pregunta que nunca es expresada con la palabra: ¿dónde estuviste? ¿Qué pasó todos estos años?, sino que es telepática. Yo le pregunto y ella me responde... creo que ese sueño está expresando esa sensación de que cuando ella aparezca, bueno, no importa..." (HABEGGER, 2001). En el caso de Los rubios, si se piensa cómo la directora plasmó una historia de más de 25 años en una hora veintitrés minutos de film, necesariamente se debe analizar la adecuación del tiempo de la historia real al tiempo del relato audiovisual (duración). Dado que la cantidad de procedimientos son limitados ${ }^{9}$ y que se trata de dos documentales basados en hechos históricos cargados de emotividad, no es casual que Carri haya utilizado los mismos que Habegger: la elipsis temporal, el resumen de hechos y la pausa descriptiva, como procedimientos para destacar momentos precisos, emociones determinadas. En este último caso, un ejemplo claro es cuando "Albertina" describe lo que no le gusta, remarcando su deseo desde niña, aún vigente: "odio las vaquitas de San Antonio y las estrellas fugaces y pasar por debajo de un puente y las vías de los trenes y los panaderos y que se te caigan las pestañas y el deseo antes de soplar las velitas en cada cumpleaños porque me pasé muchos años pidiendo que vuelva mamá y papá y todavía me pasa que no puedo evitar pensar cada vez de que soplo las velitas, que vuelva mamá, y que vuelva papá, y que vuelan pronto. En realidad es un solo

\footnotetext{
${ }^{9}$ Con respecto a la duración en narratología podemos hablar de los siguientes procedimientos: escena, pausa descriptiva, resumen, elipsis y desaceleración.
} 
deseo pero siempre lo estructuré en tres partes para que tuviera más fuerza..." (CARRI, 2003).

En el tercer caso, se hace referencia a la relación entre los acontecimientos y el relato en función de la cantidad de veces que se narra. En Historias cotidianas podemos visualizar dos opciones, dependiendo del enfoque por el que se opte: si se focaliza en la individualidad y se piensa en que son historias distintas, entonces, se está narrando "n" veces lo que ha ocurrido "n" veces. Ahora, si se considera lo sucedido como algo general, el Proceso de Reorganización Nacional como un hecho histórico general de la Argentina, entonces se puede decir que se cuenta " $n$ " veces lo que ha ocurrido una vez, desde una perspectiva diferente, personal. Según su director en una nota en Página 12, Historias cotidianas es un documental que relata " $n$ " veces " $n$ " historias, más allá de haber compartido un momento histórico en común: “junto al equipo decidimos poner el foco en lo singular, lo cotidiano, lo pequeño, hablar en presente, hablar desde hoy, desde las marcas y las huellas que llevamos dentro y que nos acompañarán siempre porque cada uno de nosotros es su propia historia." (HABEGGER, 2001) Finalmente, en relación a este punto se puede decir que Los rubios trata sobre una historia narrada una vez pero con las repeticiones, lo ecos, las remembranzas de la memoria de una niña/mujer que intenta recuperar el recuerdo de sus padres desaparecidos durante el Proceso de Reorganización Nacional.

Un último ítem a analizar es la banda sonora de estos documentales, ya que_hasta aquí se ha focalizado más en el plano de la imagen que en el sonido, sobre todo destacando éste como plano narrativo. La banda sonora de la película de Habegger está invadida por los discursos de sus protagonistas (sea en sincronía con su imagen o sobre la imagen de los otros protagonistas), pero hay dos momentos puntuales donde se entromete el "sonido ajeno" en las historias personales de modo narrativo ${ }^{10}$ : el sonido de archivo y la música del final del documental con el tema "Desapariciones" de Rubén Blades $^{11}$. En el primer caso, con el impacto del momento histórico (contextualizando) traducido en ruidos, palabras, gritos, traído al presente y, en el segundo caso, afirmando

\footnotetext{
${ }^{10}$ También hay música en algunos momentos pero auspicia sólo como ambientación, crea clima.

${ }^{11}$ Músico panameño de salsa.
} 
a modo de cierre la temática y la pluralidad de historias desde el contenido del tema musical. Tal como las historias de Úrsula, Cristian, Florencia, Victoria, Martín y Claudio, las cuáles están llenas de incógnitas y emocionalidad, el tema de Rubén Blades plantea en su letra “¿Adónde van los desaparecidos? Busca en el agua y en los matorrales. ¿Y por qué es que se desaparecen? Porque no todos somos iguales. ¿Y cuándo vuelve el desaparecido? Cada vez que los trae el pensamiento. ¿Cómo se le habla al desaparecido? Con la emoción apretando por dentro."

En el caso de la película de Carri, desde lo sonoro hay un trabajo sumamente minucioso que aporta a lo narrativo de forma más profunda, no sólo como contextualización, ambientación o acompañamiento de las imágenes, lo cual le da otro valor narrativo y contribuye a la multiplicidad de capas de sentidos. El tema musical del final “Influencia” de Charly García"2 cierra perfectamente su idea de búsqueda: "puedo ver y decir y sentir, algo ha cambiado... yo no voy a correr ni a escapar de mi destino... una parte de mi dice stop... fuiste muy lejos" mientras "Ios rubios" (representando a su familia hoy) se alejan juntos en el campo (su lugar en el mundo para la directora).

En resumen, se puede señalar que Historias cotidianas se trata de una narración sencilla dividida en capítulos, focalizada en el testimonio de seis hijos de desaparecidos: posee una banda sonora bastante austera, un relato sustentado por muy pocas intervenciones de materiales de archivo, voz en off y registro directo, con un inicio y un final plasmado en palabras escritas sobre placas que dejan en claro cuál es la intención de este documental y de quiénes se está hablando, su estructura tiene el objetivo general de demostrar cómo vivió cada uno de ellos ese trauma y cómo lo canaliza hoy; lo cual permite al espectador realizar un viaje del presente al pasado y de allí intuir, de alguna manera, la historia del director por medio de estas historias cotidianas. Por el contrario, la estructura narrativa ${ }^{13}$ de Los rubios representa la complejidad propia de los "pliegues de la memoria" de Albertina Carri: forma del fondo sobre el que imprime la gráfica, en la

\footnotetext{
${ }^{12}$ Músico argentino de rock.

13 Tal como lo manifiesta Laurence Mullaly en su artículo Albertina Carri: cineasta de la incomodidad: “Engorrosa tanto en su forma como en sus propósitos, la película es un grito de la memoria que señala la insuperable paradoja de los sobrevivientes y el carácter inalienable, indecible y único de cada experiencia." (https://cinelatino.revues.org/646)
} 
fragmentación de momentos de su historia, los intertítulos con pasajes poéticos o frases utilizadas durante la dictadura son plasmadas en pantalla, la evocación de su lugar preferido en la infancia y en donde siempre esperó que su padres regresaran (el campo) $\mathrm{y}$, sobre todo, ese sonido extradiegético que marca una especie de eco que simboliza el interior de su cabeza, etc. Una memoria que siempre está mediada por algo o por alguien, lo que tal vez sea, por un lado, una forma de representar sus recuerdos mediados por el tiempo y, por otro lado, la manera más sencilla de enfrentar el dolor, el trauma hoy ${ }^{14}$.

Pero como puede verse, más allá de las diferencias, ambos relatos se sustentan en el "presentismo", una forma de análisis de los hechos históricos que vinculan pasado/presente/futuro y por el cual el pasado determina el presente pero éste no genera certezas sobre el futuro.

\section{En definitiva...}

Luego de este recorrido, se puede afirmar que ambos directores, cada uno desde el lugar en que pudo "manejar" su relación al pasado, presenta en sus documentales una búsqueda de claridad, un modo de desahogo para sobrellevar un pasado que les resulta difícil de definir, de darle forma, y una manera de buscar cómo seguir hacia el futuro. Albertina halló en su equipo, en sus amigos, una familia (los chicos de pelucas rubias) que la sostiene y que ella elije, tal como lo manifiesta Laurence Mullaly (2014, p. 1) en el título de su artículo "Albertina Carri: cineasta de la incomodidad". Y Andrés descubrió que las historias cotidianas de otros le dieron la posibilidad de encontrar su lugar, junto a otros que padecieron lo mismo.

Habegger y Carri enfrentaron, en algún punto, el pasado de modo indirecto, lo abordaron como pudieron: uno a través de una actriz y el otro por medio de historias ajenas. Tal como el director de Historias cotidianas lo manifestara:

\footnotetext{
${ }^{14}$ Así lo expresa Carri en una entrevista: "Se generó un enorme mareo, un juego de espejos complicado que se resolvió en el momento en que me di cuenta de lo que significaba tener a otra persona haciendo de mí: esa persona podía atravesar portales que yo no podía, tenía la facultad de acercarse a lugares que yo no podía acceder, tanto emocionales como físicos." (http://www.grupokane.com.ar/index.php?option=com_content\&view=article\&id=642:artentreviacarri\& catid=36:catficcion \&ltemid=29)
} 
Quería hablar de nuestra generación, de los que sufríamos la violencia cotidiana, el secuestro y demás atrocidades siendo niños. Entonces, junto al equipo decidimos poner el foco en lo singular, lo cotidiano, lo pequeño, hablar en presente, hablar desde hoy, desde las marcas y las huellas que llevamos dentro y que nos acompañarán siempre porque cada uno de nosotros es su propia historia. En lo personal, con este documental mi historia encontró un lugar, un pequeño lugar. Ojalá sea un espejo para muchos. (HABEGGER, 2001)

Por esa razón, es importante destacar que el documental de Habegger marcó un hito en la tradición de los documentales políticos ya que fue la primera película realizada por un hijo de desaparecidos y eso dio visibilidad a una huella generacional, "la segunda generación" como la llama Aprea, la de los hijos de desaparecidos en nuestro país, lo cual pone de relieve más lo emocional, que lo político sobre tales hechos. En el caso de Carri, su documental fue uno de los más polémicos en cuanto a su abordaje sobre un tema tan susceptible, amado y odiado y, por ende, de los más analizados.

En conclusión, en Historias cotidianas se manifiestan evocaciones de la memoria de los otros (cuando me refiero a otros, me refiero a la construcción del otro como ajeno a uno, en este caso, al propio realizador) pero que de alguna manera deja entrever la empatía con la propia memoria; en cambio en Los Rubios se presenta un trabajo sobre la propia memoria, es decir, la de la realizadora. Pero a pesar de la diferencia en la hipótesis de trabajo que determina sus obras, la dificultad de delimitar el objeto histórico está dada porque ambos tratan de «trabajos de la memoria», como lo manifiesta Piedras, que repercute en la estructura y estilo narrativo, generando estructuras abiertas donde la memoria auspicia de eje temporal en el relato. Por eso, cada director se apropió de la realidad de forma disímil, personal, sustentado su relato en una serie de procedimientos, como los mencionados por María Luisa Ortega (más allá de los característicos procedimientos documentales analizados más arriba): las metáforas como el campo de Albertina/su lugar en el mundo y sus amigos/familia, las yuxtaposiciones visuales sobre los testimonios de los otros en Historias cotidianas como una forma de vínculo más allá del contenido, la poética de los temas musicales finales en ambas películas, la voz en primera persona de los implicados (Albertina, por un lado, y Cristian, Florencia, Victoria, Martín, Úrsula y Claudio Novoa, por el otro), las dramatizaciones como la de Analía Couceyro en 
el caso de Los rubios, el uso de temporalidades que no son causales sino más bien personales dado que Albertina apela a la memoria caótica y Andrés, a lo episódico (a las huellas que dejó la historia en los hijos hoy). Todo apunta a una estructura narrativa no clásica que pretende materializar una idea abstracta, una postura sobre un hecho histórico. Si bien esto es más evidente en Los rubios donde "Carri señala que sus recuerdos comenzaron en el espacio de ensueño del campo" (WILSON, 2015, p. 114) y "la búsqueda personal de sentido por parte de Carri no resulta en un cierre definitivo de hechos que pueden ser corroborados" (WILSON, 2015, p. 119), también de alguna manera sobrevuela los relatos de Historias cotidianas, donde su estructura simplemente está organizada con una lógica subjetiva (huellas, hijos, historia, hoy), despojada, centrada en los relatos incompletos de aquellos que intentan seguir con sus vidas a pesar de su pasado incierto.

Por eso nada más certero que las palabras de Gustavo Aprea (2015, p. 227), quien sostiene que estos documentales son los que plasman "la experiencia de una búsqueda destinada al fracaso" porque el eje de estas historias es la ausencia, la identidad como falta, y ahí radica su punto de encuentro exacto.

\section{Referencias}

APREA, Gustavo. Documentales, testimonios y memorias: miradas sobre el pasado militante. Buenos Aires: Manantial, 2015.

CAMPO, Javier. Documental político argentino (2007-2012). En: MARANGHELLO, César (Ed.). Cine argentino. Buenos Aires: Fondo Nacional de las Artes (en prensa), 2016.

CHANAN, Michael. El documental político después de la Guerra Fría. Comunicación y Medios: estudios sobre cine en América Latina. Santiago de Chile: Universidad de Chile, Instituto de la Comunicación e Imagen, n.24, 2011. 
CIRULO, Diego. Reflejos en la oscuridad. Entrevista a Albertina Carri. 2013. Disponible en: www.grupokane.com.ar/index.php?option=com_content\&view=article\&id=642:artentrev iacarri\&catid=36:catficcion\&ltemid=29. Acceso en: 12 septiembre 2016.

CORNER, John. Estudios sobre documental. Dimensiones de transición y continuidad. En: Cine Documental, n.6, 2012. Disponible en: http://revista.cinedocumental.com.ar/6/traducciones.html. Acceso en: 21 abril 2016.

DE LA PUENTE, Maximiliano; RUSSO, Pablo. Cine militante de los noventa. En: LUSNICH, Ana Laura; PIEDRAS, Pablo. Una historia del cine político y social en Argentina: formas, estilos y registros. Volumen II (1869-2009). Buenos aires: Editorial Nueva Librería, 2011.

HABEGGER, Andrés. Frente al espejo. 2001. Disponible en:

http://www.pagina12.com.ar/2001/01-03/01-03-21/pag31.htm. Acceso en: 5 noviembre 2016.

Historias cotidianas. Dirección: Andrés Habegger. Producción: David Blaustein. Argentina: 2001. $80 \mathrm{~min}$. Son, Color.

KAIRUZ, Mariano. En el campo las espinas. 2008. Disponible en: http://www.pagina12.com.ar/diario/suplementos/radar/9-4593-2008-05-04.html. Acceso en: 12 septiembre 2016.

Los rubios. Dirección: Albertina Carri. Producción: Marcelo Cespedes, Barry Ellsworth, Paola Pelzmajer y Pablo Wisznia. Argentina: 2003. 89 min. Son, Color.

MULLALY, Laurence. Albertina Carri: cineasta de la incomodidad. 2014. Disponible en: http://cinelatino.revues.org/646. Acceso en: 12 septiembre 2016.

NICHOLS, Bill. La representación de la realidad: cuestiones y conceptos sobre el documental. Barcelona: Paidós, 1997.

ORTEGA, María Luisa. Documental, vanguardia y sociedad. Los límites de la experimentación. En: TORREIRO, Casimiro; CERDÁN, Josetxo (Eds.). Documental y vanguardia. Madrid: Cátedra, 2005.

PIEDRAS, Pablo. Cine político y social: un acercamiento a sus categorías a través de sus debates y teorías. En: LUSNICH, Ana Laura; PIEDRAS, Pablo. Una historia del cine político y social en Argentina: formas, estilos y registros. Volumen I (1896-1969). Buenos Aires: Editorial Nueva Librería, 2009.

PIEDRAS, Pablo. El cine documental en primera persona. Buenos Aires: Paidós, 2014. 
WILSON, Kristi. Narración disociada y final abierto: resistiendo el género en Los
Albertina Carri. En: TRAVERSO, Antonio; CROWDER-TARABORRELLI, Tomás. EI documental político en Argentina, Chile y Uruguay: de los años cincuenta a la década del dos mil. Santiago de Chile: Editorial LOM, 2015.

YOLIS, Yvonne. Historias cotidianas. Sin fecha. Disponible en:

http://www.cineismo.com/criticas/historias-cotidianas.htm. Acceso en: 5 noviembre 2016.

Recebido em 12/03/2017

Aprovado em 24/05/2017

Universidade do Estado de Santa Catarina - UDESC Programa de Pós-Graduação em História - PPGH

Revista Tempo e Argumento Volume 09 - Número 21 - Ano 2017 tempoeargumento@gmail.com 